\title{
Enhancement of Cytotoxicity and Apoptosis Induction of Doxorubicin by Brazilein Containing Fraction of Secang (Caesalpinia sappan L.) on T47D Cells
}

\author{
Rohmad Yudi Utomo ${ }^{1}$, Annisa Novarina ${ }^{1}$, Prisnu Tirtanirmala ${ }^{1}$, Ria Fajarwati Kastian ${ }^{1}$, \\ Riris Istighfari Jenie ${ }^{1,2^{*}}$
}

${ }^{1}$ Cancer Chemoprevention Research Center, Faculty of Pharmacy, Universitas Gadjah Mada, Indonesia

${ }^{2}$ Departement of Pharmaceutical Chemistry, Faculty of Pharmacy, Universitas Gadjah Mada, Indonesia

\begin{abstract}
Combination chemotherapy (co-chemotherapy) is a recent strategy to reduce the toxicity effect and increase the effectivity of chemotherapeutic agent, such as Doxorubicin (Dox). Caesalpinia sappan L. are potential to be developed as co-chemoterapeutic agents due to its strong cytotoxicity toward several breast cancer cells. The purpose of this research is to observe the cytotoxicity of Brazilein containing fraction (BCF) in single and its combination with doxorubicin on T47D cells. BCF was obtained by fractionation using chloroform:ethyl acetate $(40: 60 \mathrm{v} / \mathrm{v})$ as mobile phase. Molecular docking results showed that Brazilein and Brazilin interacted with $\mathrm{Bcl}-2$ with different binding properties. Based on MTT assay, Dox and BCF performed potent cytotoxicity with IC 50 value of $403 \mathrm{nM}$ and $68 \mu \mathrm{g} / \mathrm{mL}$, respectively. BCF increased the cytotoxicity of Dox and performed synergism with $\mathrm{Cl}$ value $<\mathrm{I}$ and decreased possible toxicity with DRI value $>I$. Under Annexin $\mathrm{V}$ PI staining Flowcytometry, BCF in single and its combination with doxorubicin induced apoptosis. In conclusion, single treatment of BCF and its combination with Dox performed cytotoxic effect and induced apoptosis on T47D cell lines.
\end{abstract}

Keywords: Brazilein containing fraction, Doxorubicin, Co-chemoteraphy, Apoptosis, T47D cells

\section{INTRODUCTION}

The incidence of breast cancer cells increases gradually around the world. In Indonesia alone, there are $21.4 \%$ female patient was die caused by breast cancer (WHO, 2014). T47D cell is one of breast cancer cells with the character of p53 mutation implicating in reducing or even loss of p53 ability for cell cycle regulation (Schafer, et al., 2000). Possible strategy to overcome p53 mutated breast cancer cells was by the using of apoptosis inductor. Therefore, development of potent chemotherapy agents toward p53 mutated breast cancer cells is important to be explored.

Doxorubicin (Dox) was a common chemotherapy and potent apoptosis inductor. However, Dox also possessed as a double-edged sword chemotherapy due to its non-selective strong cytotoxicity both on cancer and normal cells. ROS induction is one of cytotoxic mechanism of doxorubicin and played role on apoptosis induction (Wang, et al., 2004). However, increasing ROS accumulation effect by Dox also induces the occurrence of several side effect such as genotoxicity, hepatotoxicity, and neurotoxicity (Kalender, et al., 2005; Ramos, et al., 2011; Tangpong, et al., 2011). Strategic approach to prevent the side effect as well as to increase the cytotoxicity of doxorubicin is by using the combination chemotherapy or co-chemotherapeutic agent (Alison, 2004). Hence, several candidates of co-chemoterapeutic agents are developed in the further research.

Submitted: Feb 21, 2018

Revised: Feb 27, 2018

Accepted: Feb 28, 2018

*Corresponding author e-mail: ririsjenie@gmail.com 
Indonesian plants that had been explored as co-chemoterapeutic agent is secang (Caesalpinia sappan L. (CS)) (Wicaksono, et al., 2008). Nurulita and Muflih, (2006) reported that the $\mathrm{IC}_{50}$ of methanolic extract of CS was $150.9 \mu \mathrm{g} / \mathrm{mL}$. Ethanolic extract of CS performed cytotoxic effect with $\mathrm{IC}_{50}$ of $35 \mu \mathrm{g} / \mathrm{mL}$ and increased cytotoxicity of doxorubicin through apoptosis induction (Nurzijah, et al., 2012). Yen, et al., (2010) reported that Brazilein, one of active compound containing in CS performed cytotoxic effect on Hep G2 and Hep 3b (liver), MDA-MB-231 and MCF-7 (breast), A549 (lung), and Ca9-22 (Oral) with $\mathrm{IC}_{50}$ value of 2-10 $\mu \mathrm{g} / \mathrm{mL}$. Brazilin, another active compound containing in CS, induced apoptosis through inactivation of histone deacetylase in multiple myeloma U266 Cells (Kim, et al., 2012). However, another compound beside brazilein and brazilin such as sappanchalcone possessed proliferative activity and predicted to decrease the cytotoxic activity of CS (Subehan, et al., 2014). Therefore, the aim of this study is to determine the cytotoxicity of purified CS extract containing brazilein namely Brazilein containing extract (BCF) in single treatment and its combination with doxorubicin toward p53 mutated T47D cells.

\section{METHODS}

\section{Sample Preparation}

Secang woods were obtained from B2P2TOOT Tawangmangu, Central Java. Dried powder of CS was extracted by $70 \%$ methanol, then it was fractinated using column chromatography using mobile phase composition of chloroform:ethyl acetate (40:60 v/v). Doxorubicin (Dox) was purchased by Sigma.

\section{Thin Layer Chromatography}

BCF was dilluted on methanol, then wass eluted on TLC by using silica gel F254 as a stationary phase and toluene:etyl acetate:methanol: formic acid (4:6:1:0,5 v/v/v) as a mobile phase. Brazilein from collection of Chemoprevention Research Center (CCRC) was used as reference standard.

\section{Molecular Docking}

Protein-Ligand Ant System (PLANTS) 1.1 software was used as molecular docking software.
The structure of $\mathrm{Bcl}-2$ protein (PDB ID: 4MAN) was downloaded from PDB. MarvinSketch (http://www.chemaxon.com/marvin/download-user. $\mathrm{html)}$ was used brazilein and brazilin preparation. Yasara (http://www.yasara.org/viewdl.htm) was used for preparing Bcl-2 as protein target. 2D and 3D visualization was performed by MOE 2010 (Licensed from Faculty of Pharmacy UGM).

\section{Cell Culture}

T47D cells were collection of Cancer Chemoprevention Research Center (CCRC) Faculty of Pharmacy UGM (obtained from Nara Institute of Science and Technology (NAIST), Japan). Dulbecco's Modified Eagle Medium (DMEM) 1640 powder (Gibco) containing $10 \% \mathrm{v} / \mathrm{v}$ Fetal Bovine Serum (FBS) (Gibco), 1,5\% penicilinstreptomycin (Gibco), 0.5\% fungizone (Gibco) were used for culture medium. Tripsin-EDTA (Gibco) $0.25 \%$ were used for cells preparation.

\section{Cytotoxicity assay}

Cytotoxicity assay was conducted according to Mosmann, (1983) with slight modification. Cells were planted on 96-well plate (Iwaki) in amount of $8 \times 10^{3}$ cells/well then were incubated at $37^{\circ} \mathrm{C} 5 \%$ $\mathrm{CO}_{2}$ overnight. Each cells were treated with various concentration of BCF and Dox for 24 hours. Cells were incubated with $0.5 \mathrm{mg} / \mathrm{mL}$ MTT (Sigma) for 4 hours, then $10 \% \mathrm{v} / \mathrm{v}$ SDS in $0.1 \mathrm{~N} \mathrm{HCl}$ (Merck) as stopper reagent was added. The absorbance was measured at $\lambda$ of $595 \mathrm{~nm}$ by using ELISA reader (Bio-Rad).

\section{Apoptosis Assay}

An amount of $5 \times 10^{4}$ cells/well were transfered to 6-well plate (Iwaki) and incubated at $37^{\circ} \mathrm{C} 5 \% \mathrm{CO}_{2}$ condition. Cells were treated by $\mathrm{BCF}$, Dox, and their combination for 24 hours. Cells were centrifugated and added by 100 annexin V-FITC which was diluted in binding buffer. Cells were incubated for 15 minutes and analyzed with flowcytometry at $\lambda$ of $488 \mathrm{~nm}$.

\section{Data Analysis}

Molecular Docking. $\mathrm{f}_{\text {PLP }}$ score was used as parameter of affinity, lower $\mathrm{f}_{\mathrm{PLP}}$ score indicated stronger affinity. Single Cytotoxicity assay. $\mathrm{IC}_{50}$ value was used as parameter of cytotoxicity. Combinational Cytotoxicity Assay. Combination 
Index (CI) value (CI $>1$, antagonism; $\mathrm{CI}=1$, additive, $\mathrm{CI}<1$, synergism) was used as parameter of cytotoxicity of combination while Dose Reduction Index (DRI) value (DRI $>1$, decreased toxicity) was used as parameter of toxicity prediction (Chou, 2010). Apoptosis Assay. Cells on each quadrant represented as viable cells (lower left), early apoptosis (lower right), late apoptosis (upper right), and necrosis (upper left).

\section{RESULTS}

\section{Verification of Brazilein Content on BCF by Thin Layer Chromatography Analysis}

The purpose of o-chemoterapeutic agents was to decrease the dose of chemotherapy in order to prevent the occurrence of side effect as well as to increase the anticancer activity of chemotherapy. Prospective chemopreventive activity of CS drived to explore the active compound containing in CS. Brazilein (Fig. 1A) and Brazilin, two major compound of CS possessed potent cytotoxic effect toward several cancer cells. In contrary, another compound in CS such as chromanone and its derivatives exists as estrgonic agent and is possibly antagonist the cytotoxic effect of CS (Lai, et al., 2011). Laksmiani, et al., (2015) had successfull isolated brazilein from ethanolic extract of $\mathrm{CS}$, however the $\%$ yield Brazilein was only $8 \% \mathrm{w} / \mathrm{w}$.
Due to the limitation of isolation techique, fractination became a potential approach because of its advantages such as, less solvent extraction, simple separation technique, and faster than isolation. Therefore, in this study we focus explore the prospect of BCF as a novel co-chemoterapeutic agent. First, we determined the presence of Brazilein on BCF by Thin Layer Chromatograpgy. Both Be and BFC showed similar hRf value of 65 under visible light, UV $254 \mathrm{~nm}$, and UV $366 \mathrm{~nm}$ (Fig. 1B). Therefore, BCF was confrimed to contain Be and was valid to be used for cytotoxicity study.

\section{BCF and its Combination with Dox Performed Cytotoxic Effect on T47D Cells}

Cytotoxicity of CS correlated with the presence of Be content. BCF had been confirmed to contain $\mathrm{Be}$, therefore possibly possessed cytotoxic effect. T47D was used as a model of breast cancer cells and expressed estrogen receptor (ER), progesterone receptor, caspase 3 , caspase 7 , and mutated p53 (Schafer, et al., 2000). The cytotoxicity study using MTT assay on T47D cells was carried out to evaluate the cytotoxicity of single tretament BCF and its potency to incerased the cytotoxicity of Dox. Single treatment of BCF and Dox decreased cells viability in a dose dependent manner with $\mathrm{IC}_{50}$ value of $68 \mu \mathrm{g} / \mathrm{mL}$ and $402 \mathrm{nM}$, respectively (Fig. 2A and 2B).
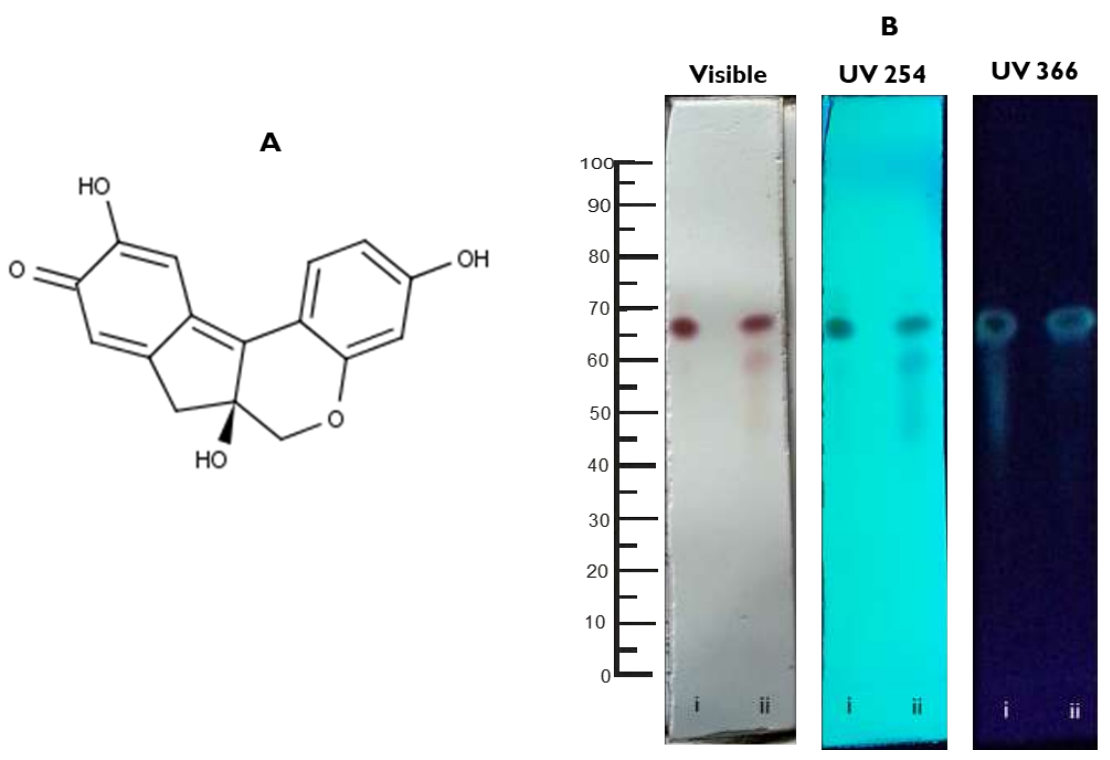

Figure I. Phytochemical Profile of Brazilein Containing Fraction (BCF) by Thin Layer Chromatography (TLC). A. Chemical Structure of Be. B. TLC profile of Be (i) and BCF (ii). Sample Be and BCF was diluted in ethanol then was spotted on Silica Gel GF 254 . Elution was performed by as mobile phase, then was subjected to visible light and UV light. hRf 65 indicated as spot of Be. 
After combination treatment, various concentration of BCF increased cytotoxicity of Doxorubicin after $24 \mathrm{~h}$ treatment. Intersetingly, Both combination of BCF $(23 \mu \mathrm{g} / \mathrm{mL})$ with Dox $(134 \mu \mathrm{M})$ and BCF $(34 \mu \mathrm{g} / \mathrm{mL})$ with Dox $(201 \mu \mathrm{M})$ decreased cells viability up to $15 \%$ (Fig. 2C). Under isobologram analysisi, all combination of BCF and Dox performed synergism $(\mathrm{CI}<1)$ and predicted to decrease the toxicity of Dox (DRI $<1)$ (Table 1 and 2). Based on Omoyeni, et al., (2014), BCF was classified as strong cytotoxic agent due to the $\mathrm{IC}_{50}<$ $100 \mu \mathrm{g} / \mathrm{mL}$. On the other side, $\mathrm{IC}_{50}$ value of methanolic extract and ethanolic extract of CS were
150 and $34 \mu \mathrm{g} / \mathrm{mL}$, respectively (Nurulita and Muflih, 2006; Nurzijah, et al., 2012). Therefore, cytotoxicity of BCF was more potent than methanolic extract but less potent than ethanolic extract of CS. The results indicated that there were another compound containing on ethanolic extract of CS played role on cytotoxicity of CS beside Brazilein and Brazilin. Overall, BCF performed strong cytotoxic effect and increased the cytotoxicity of Dox on T47D cells. Cytotoxicity of BCF need to be confirmed by the cell cycle modulation activity and apoptosis induction.
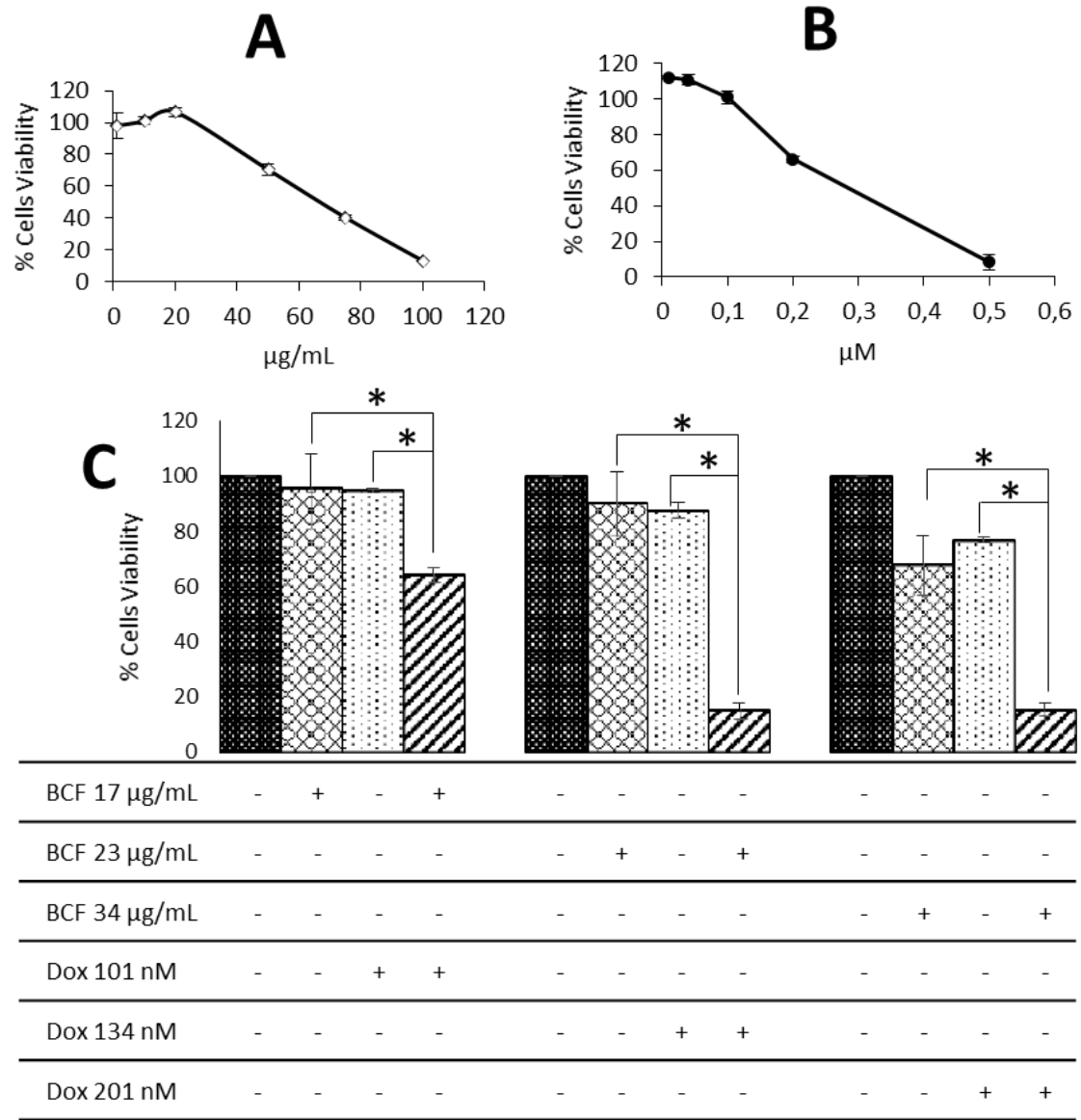

Figure 2. Cytotoxicity of BCF in single and its combination on T47D Cells. A. Cytotoxic Effect of BCF on T47D Cells. B. Cytotoxic Effect of Dox T47D Cells. Cells were plated on 96-well plates then were treated by single treatment of $\mathrm{BCF}$ or Dox in various concentration. After regresion analysis, we obtained $\mathrm{IC}_{50}$ values of $\mathrm{BCF}$ and Dox on T47D was $68 \mu \mathrm{g} / \mathrm{mL}$ and $402 \mu \mathrm{M}$. C. Cytotoxic Effect of BCF and Dox Combination on T47D Cells. Cells were plated on 96-well plates then were treated by combination of BCF and Dox in various concentration. Data expressed as the mean \pm standard deviations (SD) from three independent experiments. Statistical data were analysed by one way Anova followed by Post Hoc analysis by Tukey $(p<0.05)$ 
Table I. Combination Index (CI) Value of BCF and Dox Combination

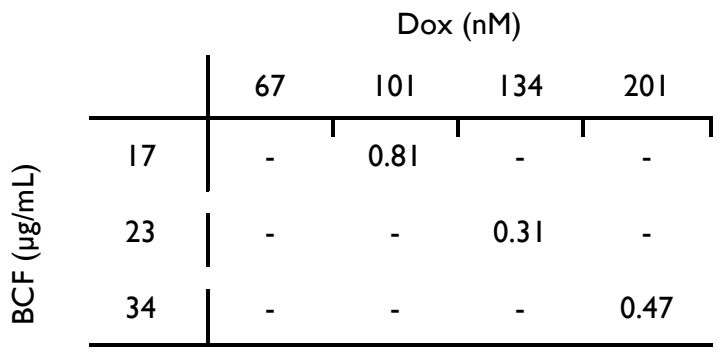

Table 2. Dose Reduction Index (DRI) value of BCF and Dox Combination

\begin{tabular}{ccc}
\hline No & \multicolumn{2}{c}{ DRI } \\
& BCF $(\mu \mathrm{g} / \mathrm{mL})$ & Dox $(\mathrm{nM})$ \\
\hline 1 & 2.27 & 2.73 \\
2 & 6.12 & 6.76 \\
3 & 4.09 & 4.52 \\
\hline
\end{tabular}

Apoptosis Induction of BCF and its Combination with Doxorubicin on T47D Cells

Several chemopreventive and cochemoterapeutic agents induced apoptosis through intrinsic and extrinsic pathway. CS had been known to induced apoptosis on T47D, MCF-7, and HeLa cell lines through induction of DNA fragmentation and caspase 3 activation (Hung, et al., 2014; Khamsita, et al., 2012; Nurzijah, et al., 2012). Dox also known to induce apoptosis through increasing ROS intracelluer both on cancer cells and normal cells (Wang, et al., 2004). Therefore, the used BCF was applied in order to diminish the non-selective apoptosis induction of Dox. Under, Annexin V PI Flowcytometry, we found that single treatment of BCF $34 \mu \mathrm{g} / \mathrm{mL}$ was more potent to induce apoptosis than Dox $201 \mathrm{nM}$ with precentage cells were $81 \%$ and $50 \%$, respectively. However, BCF also induced necrosis with precentage cells were $6 \%$. Interestingly, combination of $\mathrm{BCF}$ and Dox were more potent to induced apoptosis than single treatment of both compound with precentage cells were $86 \%$ and decreased precentage of necrosis cells up to $0.05 \%$. Hence, combination of BCF and Dox performed cytotoxic effect and performed synergism to induce apoptosis (Fig. 3). 

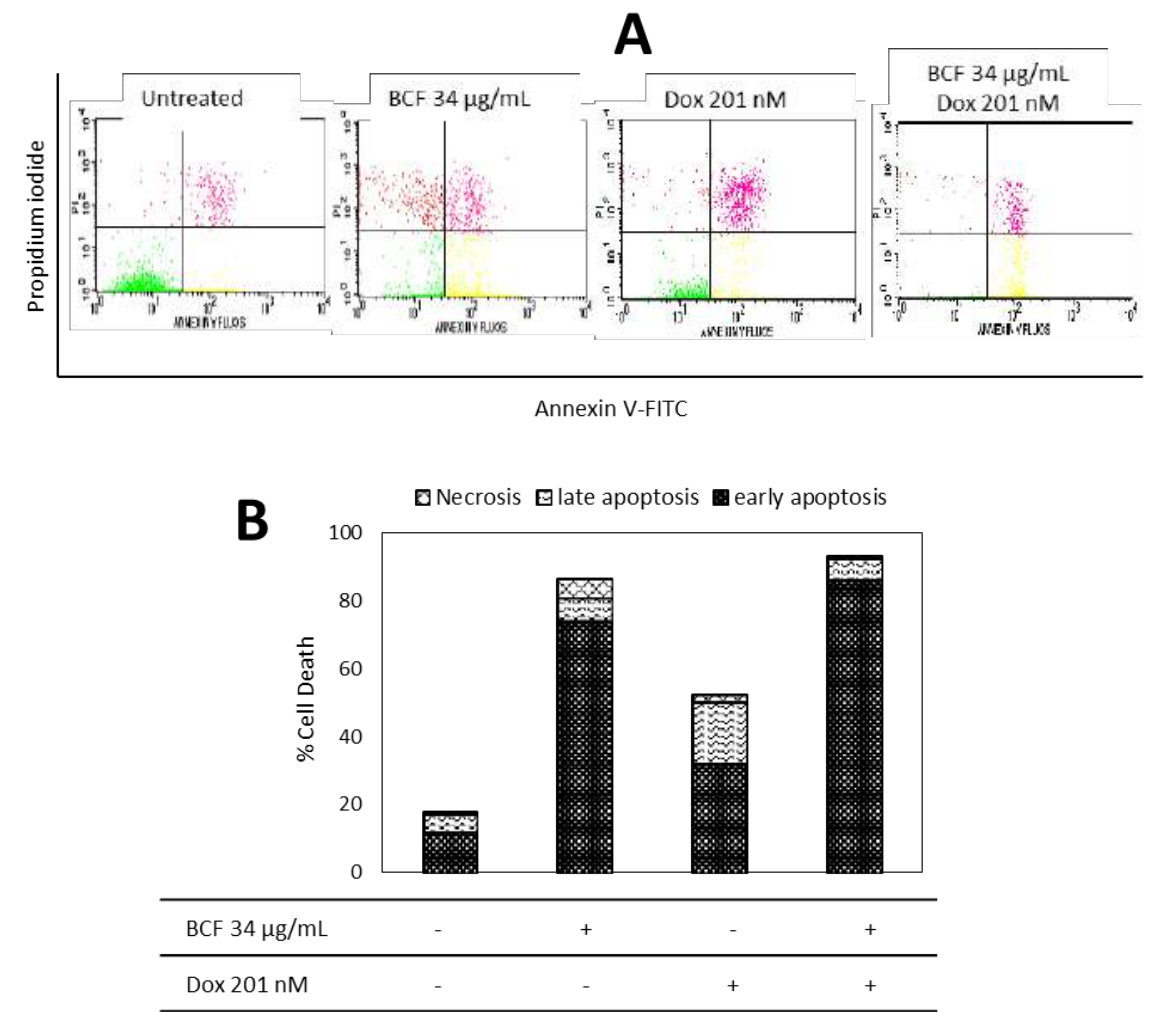

Figure 3. Single Treatment of BCF and Its Combination with Dox Induced Apoptosis on T47D Cells. A. Typical quadrant analysis of Annexin V-FITC/Propidium lodide flowcytometry of T47D cells treated with BCF and its combination with Dox. B. Quantification of cell death in each groups.

Apoptotic induction by Doxorubicin requires p53 (Drummond, 2008). The p53 gene is a suppressor gene tumor that is involved in apoptotic induction. T47D cells are cells with mutated p53, so it is possible that BCF induce apoptosis via a p53independent pathway. One of strategic target on p53independent pathway was the inhibition of $\mathrm{Bcl}-2$ protein. Bcl-2 family proteins were an important proteins located on the outer membrane of mitochondria due to its role as anti-apoptosis protein by increasing the time-to-death and cell-to-cell variability (Skommer, et al., 2010). Overexpression of Bcl-2 proteins, prevented the release of cytochrome $\mathrm{c}$ from mitochondria, and was responsible for the survival of many types of cancer cells such as breast and prostate cancer (Fernández, et al., 2002). Therefore, the study of potential role of $\mathrm{BCF}$ on Bcl-2 protein need to be conducted.

\section{Binding Interaction Profile of Active Compound Containing on BCF with Bcl-2}

BCF showed potent cytotoxicity both in single and combination with Dox through apoptotic induction. The prediction of potential target of $\mathrm{BCF}$ related to apoptotic induction can be conducted by molecular docking. Molecular docking was a powerfull tools to predict the interaction of compound with receptor. Docking studies were performed on anti-apoptotic preotein Bcl-2 (PDB ID: $4 \mathrm{MAN}$ ) and compound containg on $\mathrm{BCF}$, Brazilein and Brazilin. Navitocalx derivatives, ABT-199, was used as a known ligand native possessed as inhibtor of anti-apoptosis protein. ABT-199 inhibited the growth of Bcl-2-dependent tumors in vivo and spares human platelets (Souers, et al., 2013). Based on molecular docking PLANTS results, both Brazilein and Brazilin performed higher $\mathrm{f}_{\mathrm{PLP}}$ score than native ligand (Table 3). Visualization interaction analysis showed that native ligand interacted with amino acid residue of PHE 127 and ARG 56, however Brazilein only interacted with amino acid residue of GLY 151 (Table 3 and Fig. 4). Interestingly, Brazilin interacted with more various amino acid residue than native ligand and Brazilein such as ILE 144, VAL 145, and PHE 150 (Table 3 and Fig. 4). In general, Brazilein and Brazilin interacted with Bcl-2 with different binding properties compared to native ligand and possibly play role the cytotoxicity of BCF on T47D cells through apoptotic induction. 
Table 3. fPLP Score and Binding Properties of Active Compound of BCF on Bcl-2

\begin{tabular}{clclllll}
\hline No & \multicolumn{1}{c}{ Ligand } & fPLP & \multicolumn{4}{c}{ Binding Properties } & RMSD \\
\cline { 4 - 6 } & & score & Ligand & Residue & Binding Type & Distance & (A) \\
\hline I & ABT-199 (native & -149.94 & N I323 & PHE I27 & H-Bond & I.97 & 2.00 \\
& ligand) & & O I330 & ARG 56 & H-Bond & 2.49 & \\
\hline 2 & Brazilein & -76.5 I & N 723 & GLY I5I & H-Bond & 2.09 \\
\hline 3 & Brazilin & -74.34 & O I287 & ILE I44 & H-Bond & 2.22 \\
& & & O I287 & VAL I45 & H-Bond & 2.07 & \\
& & O I269 & PHE I50 & H-Bond & 2.5 I \\
\hline
\end{tabular}

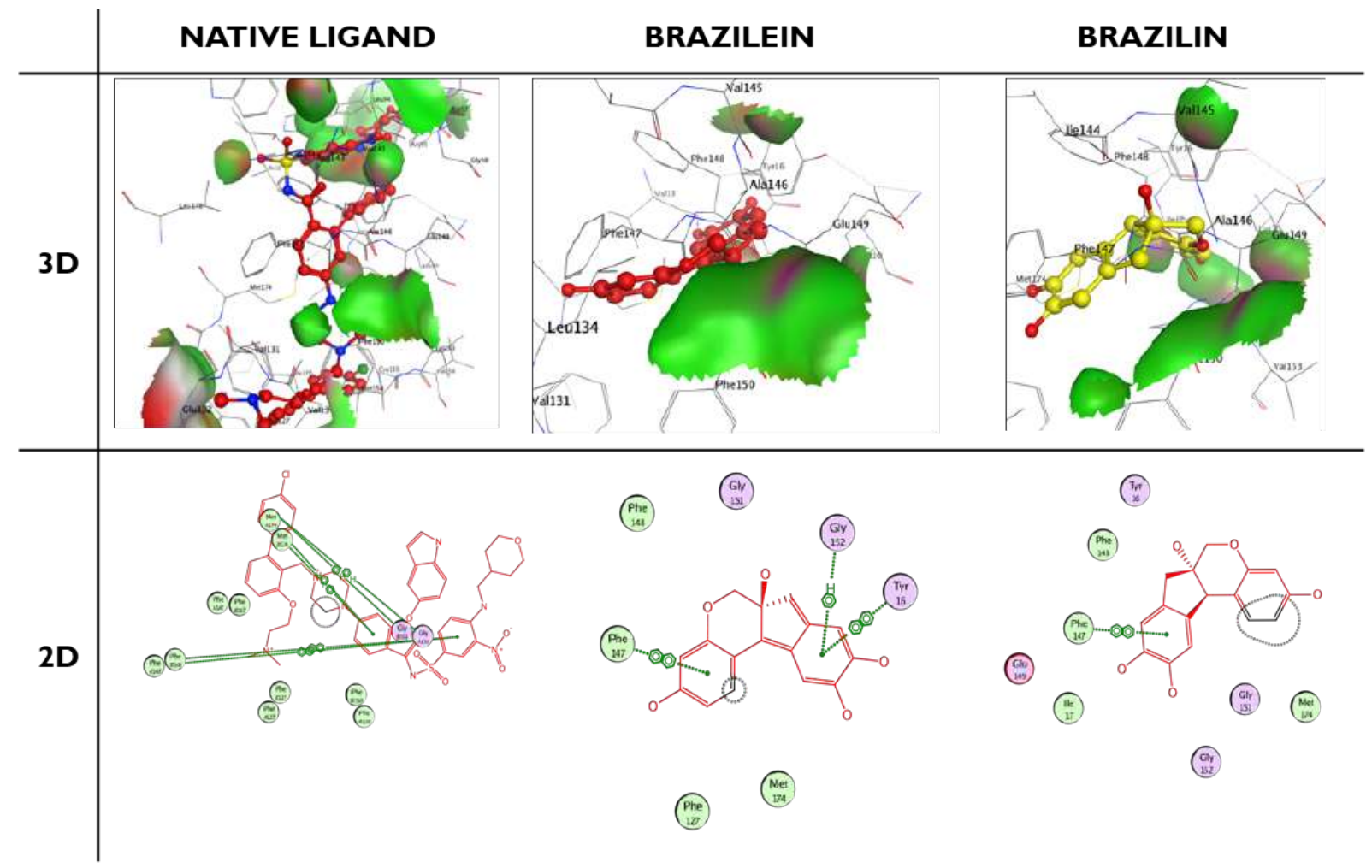

Figure 4. Visualization Interaction of Brazilein and Brazilin on Bcl-2. A. 3D interaction of Brazilein and Brazilin with Bcl-2. Green color represented as hydrophobic binding, Purple color represented as polar bindng, Red color represented as exposed binding. B. 2D Ligand interaction of Brazilein and Brazilin with Bcl-2. Purple color represented as polar binding, grean color represented as greasy binding.

Inhibition of Bcl-2 possessed as strategic method to induce apoptosis on p53-mutated cells with loss most of pro-apoptotic protein expression (Rathore, et al., 2017). Known target of Brazilin on apoptotic induction are increasing of cleavage caspase 3, cleavage caspase 7 and cleavage PARP Interaction (Lee, et al., 2013), while Brazilein inhibits the anti-apoptotis protein (Zhong, et al., 2009). Our findings provided a new target of Brazilein and Brazilin underlying the apoptosis induction on p53-mutated cells by targeting Bcl-2 proteins. Further research needs to confirm chemical or physical interaction of Brazilein and Brazilin with anti-apoptotis protein especially Bcl-2 in order to develop BCF as novel cochemoterapeutic agent.

\section{CONCLUSION}

Brazilein containing fraction exhibits cytotoxic effect and induced apoptosis toward T47D cells. 


\section{ACKNOWLEDGMENT}

We expressed our gratitude to Prof. Masashi Kawaichi who kindly gift the T47D cells in this research experiment.

\section{REFERENCES}

Alison, M.R., 2004, The Cancer Handbook, New York: Wiley.

Chou, T.C., 2010, Drug Combination Studies and Their Synergy Quantification Using the ChouTalalay, Method Cancer Res., 70(2), 440-446.

Drummond, C., 2008, The Mechanism of Anti-Tumour Activity of the DNA Binding Agent, Thesis, Research Space, Auckland.

Fernández, Y., Gu, B., Martínez, A., Torregrosa, A. and Sierra, A., 2002, Inhibition of Apoptosis in Human Breast Cancer Cells: Role in Tumor Progression To The Metastatic State, Int. J. Cancer, I 0 I (4), 317-326.

Hung, T.M., Dang, N.H. and Dat, N.T., 2014, Methanol Extract from Vietnamese Caesalpinia Sappan Induces Apoptosis in Hela Cells, Biol. Res., 47: 20. doi: 10.1/86/07/76287-47-20.

Kalender, Y., Yel, M. and Kalender, S., 2005, Doxorubicin Hepatotoxicity and Hepatic Free Radical Metabolism in Rats: The Effects of Vitamin E and Catechin, Toxicology, 209(I), 39-45.

Khamsita, R., Hermawan, A., Putri, D.D.P. and Meiyanto, E., 2012, Ethanolic Extract of Secang (Caesalpinia sappan L.) Wood Performs as Chemosensitizing Agent Through Apoptotic Induction on Breast Cancer MCF-7 Cells, Indones. J. Cancer Chemoprevent., 3(3), 444-449.

Kim, B., Kim, S.H., Jeong, S.J., Sohn, E.J., Jung, J.H., Lee, M.H., et al., 20I2, Brazilin Induces Apoptosis and G2/M Arrest via Inactivation of Histone Deacetylase in Multiple Myeloma U266 Cells, J. Agric. Food Chem., 60(39), 98829889.

Lai, W.C., Wang, H.C., Chen, G.Y., Yang, J.C., Korinek, M., Hsieh, C.J., et al., 20II, Using the pER8:GUS Reporter System to Screen for Phytoestrogens from Caesalpinia sappan, J. Nat. Prod., 74(8), 1698-1706.
Laksmiani, N.P.L., Susidarti, R.A. and Meiyanto, E., 2015, Brazilein Increased Cytotoxic Activity of Doxorubicin on MCF-7/DOX Cells, Indones. J. Cancer Chemoprevent., 6(2), 58-63.

Lee, D.Y., Lee, M.K., Kim, G.S., Noh, H.J. and Lee, M.H., 2013, Brazilin Inhibits Growth and Induces Apoptosis in Human Glioblastoma Cells, Molecules, I 8(2), 2449-2457.

Mosmann, T., 1983, Rapid Colorimetric Assay for Cellular Growth and Survival: Application to Proliferation and Cytotoxicity Assays, J. Immunol. Methods, 65(I-2), 55-63.

Nurulita, N.A. and Muflih, Y.A., 2006, Efek Sitotoksik Ekstrak Metanol Kayu Secang (Caesalpinia sappan L.) pada Sel Kanker Payudara T47D melalui Induksi Apoptosis, Pharmacy, 4(I), I-9.

Nurzijah, I., Putri, D.D.P., Rivanti, E. and Meiyanto, E., 2012, Secang (Caesalpinia sappan L.) Heartwood Ethanolic Extract Shows Activity as Doxorubicin Co-chemotherapeutic Agent by Apoptotis Induction on T47D Breast Cancer Cells, Indones. J. Cancer Chemoprevent., 3(2), 376-383.

Omoyeni, O.A., Meyer, M., Iwuoha, E., Green, I. and Hussein, A.A., 2014, An Unusual 2,3Secotaraxerene and Other Cytotoxic Triterpenoids from Pleiocarpa pycnantha (Apocynaceae) Leaves Collected from Nigeria, Molecules, I9(3), 3389-3400.

Ramos, D.L., Gaspar, J.F., Pingarilho, M., Gil, O.M., Fernandes, A.S., Rueff, J., et al., 20II, Genotoxic Effects of Doxorubicin in Cultured Human Lymphocytes with Different Glutathione S-Transferase Genotypes, Mutat. Res. Toxicol. Environ. Mutagen, 724(I-2), 2834.

Rathore, R., McCallum, J.E., Varghese, E., Florea, A.M. and Büsselberg, D., 2017, Overcoming Chemotherapy Drug Resistance by Targeting Inhibitors of Apoptosis Proteins (IAPs), Apoptosis Int. J. Program. Cell Death, 22(7), $898-919$.

Schafer, J.M., Lee, E.S., O'Regan, R.M., Yao, K. and Jordan, V.C., 2000, Rapid Development of Tamoxifen-stimulated Mutant p53 Breast Tumors (T47D) in Athymic Mice, Clin. Cancer Res., 6(I I), 4373-4380. 
Skommer, J., Brittain, T. and Raychaudhuri, S., 2010, Bcl-2 Inhibits Apoptosis by Increasing the Time-to-Death and Intrinsic Cell-to-Cell Variations in the Mitochondrial Pathway of Cell Death, Apoptosis, I5(10), 1223-1233.

Souers, A.J., Leverson, J.D., Boghaert, E.R., Ackler, S.L., Catron, N.D., Chen, J., et al., 2013, ABT199, A Potent and Selective BCL-2 Inhibitor, Achieves Antitumor Activity While Sparing Platelets, Nat. Med., 19(2), 202-208.

Subehan, Rifai, Y., Mufidah, Ismail, Aswad, M. and Morita, H., 2014, Phytochemical Investigation of the Active Constituents from Caesalpinia Sappan on Stimulation of Osteoblastic Cells, Plant. Biotechnol., 3 I (5), 505-509.

Tangpong, J., Miriyala, S., Noel, T., Sinthupibulyakit, C., Jungsuwadee, P. and St. Clair, D.K., 20II, Doxorubicin-Induced Central Nervous System Toxicity and Protection by Xanthone Derivative of Garcinia Mangostana, Neuroscience, 175, 292-299.

Wang, S., Konorev, E.A., Kotamraju, S., Joseph, J., Kalivendi, S. and Kalyanaraman, B., 2004,
Doxorubicin Induces Apoptosis in Normal and Tumor Cells via Distinctly Different Mechanisms Intermediacy of H2O2- and p53Dependent Pathways, J. Biol. Chem., 279(24), 25535-25543.

WHO, 20I4, WHO | Cancer Country Profiles 20I4, http://www.who.int/cancer/country-profiles/ en/, Cited February 2, 2018).

Wicaksono, B.D., Arung, E.T. and Sandra, F., 2008, Aktivitas Antikanker dari Kayu Secang, CDK 35(162), 133-137.

Yen, C.T., Nakagawa-Goto, K., Hwang, T.L., Wu, P.C., Morris-Natschke, S.L., Lai, W.C., et al., 2010, Antitumor Agents. 27I: Total Synthesis and Evaluation of Brazilein and Analogs as Anti-inflammatory and Cytotoxic Agents, Bioorg. Med. Chem. Lett, 20(3), 1037-1039.

Zhong, X., Wu, B., Pan, Y. and Zheng, S., 2009, Brazilein Inhibits Survivin Protein and mRNA Expression and Induces Apoptosis in Hepatocellular Carcinoma Hepg2 Cells, Neoplasma, 56(5), 387-392. 